\title{
Saturated $\mathrm{pH}$ and Total Inorganic Carbon from $\mathrm{CO}_{2}$ Solubility Related to Algal Growth
}

\author{
C. Dasaard ${ }^{1}$, D. J. Bayless ${ }^{2}$, B. J. Stuart ${ }^{3}$ \\ Department of Mechanical Engineering, Academic Division, Chulachomklao Royal Military Academy (CRMA), \\ Muang, Nakhon nayok, Thailand ${ }^{1}$ \\ Dept of Mechanical Engineering, Russ College of Engineering \& Technology, Ohio University, Athens OH USA ${ }^{2}$ \\ Department of Civil \& Environmental Engineering, Old Dominion University, Norfolk VA, USA ${ }^{3}$
}

\begin{abstract}
Solubility of $\mathrm{CO}_{2}$ in media formed one-or-more of four forms of inorganic carbon species: carbonic acid, aqueous carbon dioxide, bicarbonate, and carbonate and generated hydrogen ion affecting the medium $\mathrm{pH}$. The saturated TIC and $\mathrm{pH}$ were studied using RO water, RO+, GM and GM+ with air $(0.038 \%), 0.5 \%, 1.0 \%, 1.5 \%, 2.0 \%$ and $10 \% \mathrm{CO}_{2}$ under atmospheric pressure at temperatures of $25,35,45$, and $55^{\circ} \mathrm{C}$. Chemical species existing in the media formed additional inorganic carbon species functioning as a buffer, resulting in raising the medium $\mathrm{pH}$. The $\mathrm{NaOH}$ boosted the TIC holding capacity of the media and improved the saturated $\mathrm{pH}$. At a specific $\mathrm{CO}_{2}$-enriched air and medium, the saturated $\mathrm{pH}$ linearly increased with respect to increased temperature, which implied the decreasing of TIC. However, the saturated TIC concentration nonlinearly decreased with respect to temperature. At a specific medium and temperature, the saturated $\mathrm{pH}$ nonlinearly decreased with respect to increased $\mathrm{CO}_{2}$ concentration whereas the TIC concentration linearly increased with respect to increased $\mathrm{CO}_{2}$-enriched air. At a specific $\mathrm{CO}_{2}$-enriched air, medium and temperature, increasing of TIC concentration decreased the medium $\mathrm{pH}$. The saturated TIC and $\mathrm{pH}$ became stable at a same period of time; however, the correlation of the TIC and $\mathrm{pH}$ was invalid. The saturated $\mathrm{pH}$ can be used to specify the saturation condition of TIC.
\end{abstract}

Keywords: Solubility of $\mathrm{CO}_{2}$, Total inorganic carbon, saturated pH, Algal Growth

\section{INTRODUCTION}

This study is to investigate changes in $\mathrm{pH}$ of defined media corresponding to changes in total inorganic carbon (TIC) concentration during the $\mathrm{CO}_{2}$ mass transfer from the absorption of gaseous $\mathrm{CO}_{2}$. The fraction of TIC depends on the equilibrium $\mathrm{pH} . \mathrm{CO}_{2}$ dissolves into ground water or media in a series of chemical reaction and becomes aqueous $\mathrm{CO}_{2}$, carbonic acid, bicarbonate and carbonate as shown in Equations (1) - (4).

During this process, not only is inorganic carbon formed, but also free hydrogen ions, which decrease media $\mathrm{pH}$.

This can be simply calculated using $p H=-\log _{10}\left[H^{+}\right]$, where $\left[\mathrm{H}^{+}\right]$is a molarity of the hydrogen ion. The simple formula for $\mathrm{pH}$ calculation becomes very complex when the media consists of several chemical species at a wide range of temperatures, pressures and $\mathrm{CO}_{2}$ concentrations.

$$
\begin{aligned}
& \mathrm{CO}_{2}(\mathrm{~g}) \leftrightarrow \mathrm{CO}_{2}(a q) \\
& \mathrm{CO}_{2}(a q)+\mathrm{H}_{2} \mathrm{O} \leftrightarrow \mathrm{H}_{2} \mathrm{CO}_{3}(a q) \\
& \mathrm{H}_{2} \mathrm{CO}_{3}^{*}(a q) \leftrightarrow \mathrm{HCO}_{3}^{-}+H^{+} \\
& \mathrm{HCO}_{3}^{-} \leftrightarrow \mathrm{CO}_{3}^{2-}+\mathrm{H}^{+}
\end{aligned}
$$

The distribution of these inorganic carbon species is $\mathrm{pH}-$ dependent as shown in Fig.1, where that aqueous $\mathrm{CO}_{2}$
$\left(\mathrm{H}_{2} \mathrm{CO}_{3}^{*}\right)$ predominates when the $\mathrm{pH}$ falls below 6.3, $\mathrm{HCO}_{3}^{-}$predominates at $\mathrm{pH}$ values between 6.3 and 10.3 , and $\mathrm{CO}_{3}^{2-}$ is the major species at $\mathrm{pH}$ values above 10.3 [14].

Media $\mathrm{pH}$ is an important factor that could identify availability of inorganic carbon species for an aquatic photosynthetic organism and is one of crucial parameters influencing growth of algae [4-12]. According to Bano and Siddiqui, cyanobacterial species preferred to grow near neutral to alkaline $\mathrm{pH}$ and have growth optimum at near neutral [13-14].

Yet, there are numerous exceptions. Several studies have reported that many extremophiles can adapt to grow best at extreme $\mathrm{pH}$; for example, cyanobacteria, Oscillatoria/Limnothrix and Spirulina sp. could tolerate on acidic environments of $\mathrm{pH} 2.9$ [15]. In contrast, 13 alkaliplilic cyanobacteria were reported to grow under alkaline conditions, but could not grow well under a neutral-pH condition [16].

Maintaining proper media $\mathrm{pH}$ is useful to help specific strains of algae to receive the desired inorganic carbon species and to ensure that the most favored inorganic carbon species for their carbon concentration mechanism are sufficient. 


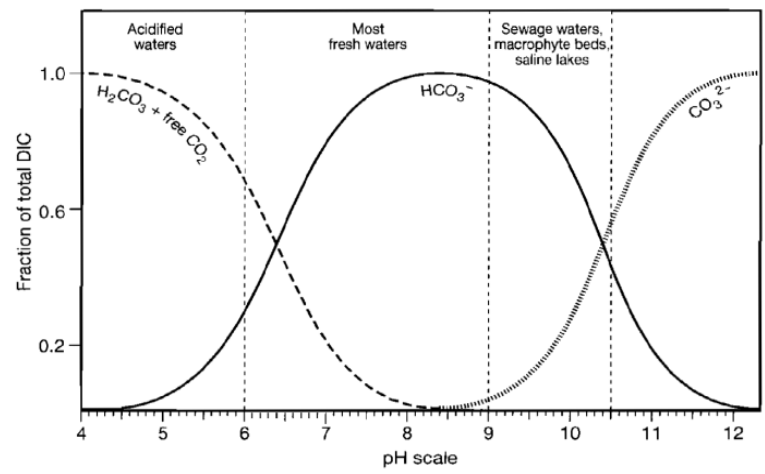

Fig.1. Distribution of inorganic carbon forms in rivers and lakes with respect to changes in $\mathrm{pH}$ [1]

Therefore, correlation of the media $\mathrm{pH}$ to TIC concentration using experimental and computational calculations could be a very useful tool in predicting photosynthetic behavior by understanding TIC concentration and speciation.

\section{PH MEASUREMENT}

Media $\mathrm{pH}, \quad \mathrm{CO}_{2}$-enriched air concentrations and temperature were recorded using the Campbell scientific CR1000 data acquisition system as described in experimental setup [17] for reverse osmosis (RO) water and growth media (GM), RO with $3 \mathrm{mM} \mathrm{NaOH}(\mathrm{RO}+)$ and $\mathrm{GM}$ with $3 \mathrm{mM} \mathrm{NaOH}(\mathrm{GM}+)$ at temperatures of 25 , 35,45 , and $55^{\circ} \mathrm{C}$ and gas phase $\mathrm{CO}_{2}$ concentrations of air (380 ppm), $0.5 \%, 1.0 \%, 1.5 \%, 2 \%$ and $10.0 \%$.

In addition, $0.1 \% \quad \mathrm{CO}_{2}$ concentration was used to investigate $\mathrm{pH}$ changes in $\mathrm{GM}+$. During the $\mathrm{CO}_{2}$ mass transfer, TIC concentration was measured approximately every six minutes using an OI TOC analyzer in a continuous mode. Media $\mathrm{pH}$ was recorded during the same time period as TIC sampling for direct comparison.

A Thermo Scientific submersible automated temperature compensated $\mathrm{pH}$ probe and its display and read out accessory, Model alpha pH500 2-Wire pH/ORT transmitter $\mathrm{pH} / \mathrm{mV} /{ }^{\circ} \mathrm{C}$, was used to monitor the media $\mathrm{pH}$. The alpha pH500 displays $\mathrm{pH}$ from 0.00 to 14.00 with resolution and accuracy of $0.01 \mathrm{pH}$ and $\pm 0.01 \mathrm{pH}$, respectively.

The submersible $\mathrm{pH}$ probe is appropriate for a temperature range from -10.0 to $110.0^{\circ} \mathrm{C}$ with resolution and accuracy of $0.1{ }^{\circ} \mathrm{C}$ and $\pm 0.5^{\circ} \mathrm{C}$, respectively. The output of the display and read out was connected to the Campbell scientific CR1000 data acquisition and programmed to the data acquisition system. Temperature, $\mathrm{pH}$, and gas phase $\mathrm{CO}_{2}$ concentrations were recorded every minute.

An air flow rate of approximately 18.7 LPM was blended with $\mathrm{CO}_{2}$ to achieve the desired $\mathrm{CO}_{2}$ concentration. Bubbling of this mixture into a $3 \mathrm{~L}$ Erlenmeyer flask was initiated after the data acquisition system was activated.

\section{EXPERIMENTAL RESULTS}

\section{A. TIC Concentration and Media $\mathrm{pH}$ as a function of Time}

Fig. 2 plots TIC concentration as a function of time until saturation for each temperature tested for a gas phase $\mathrm{CO}_{2}$ level of $0.1 \%$ in growth media plus $3 \mathrm{mM}$ of $\mathrm{NaOH}$ $(\mathrm{GM}+)$. Fig. 3 plots the media $\mathrm{pH}$ over the same time interval as TIC concentration measurements in Fig. 2. The data in Figs. 2 and 3 show that increasing TIC concentration decreased the media $\mathrm{pH}$.

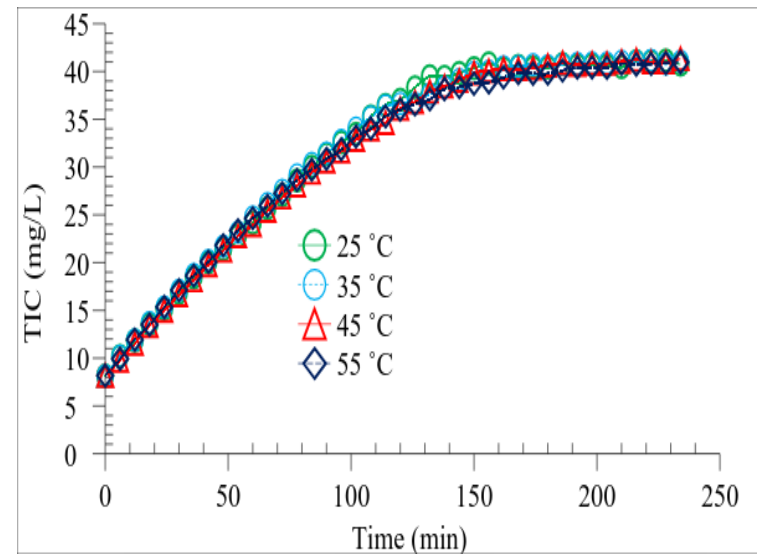

Fig. 2. TIC Concentrations in $\mathrm{GM}+$ with $0.1 \% \mathrm{CO}_{2}$

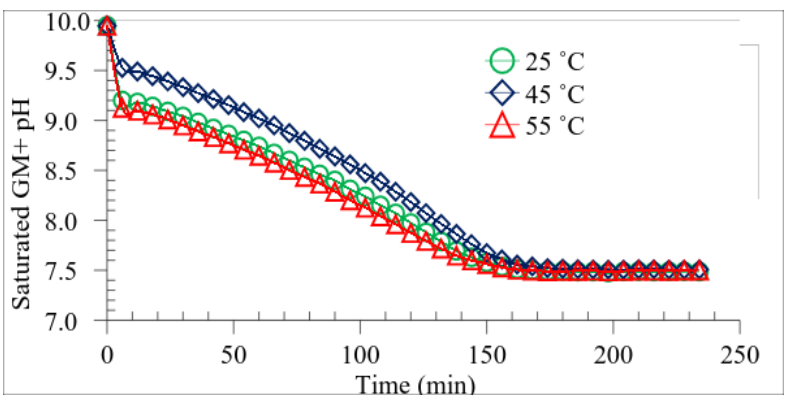

Fig. 3. $\mathrm{GM}+\mathrm{pH}$ with $0.1 \% \mathrm{CO}_{2}$

Data shown in Figs. 4 - 7 illustrate the changes in $\mathrm{pH}$ and TIC concentrations for two media (GM and $\mathrm{GM}+$ ) at $25^{\circ} \mathrm{C}$ for gas phase $\mathrm{CO}_{2}$ concentrations of air (380 ppm), $0.5 \%$, $1.0 \%, 1.5 \%, 2 \%$ and $10.0 \%$.

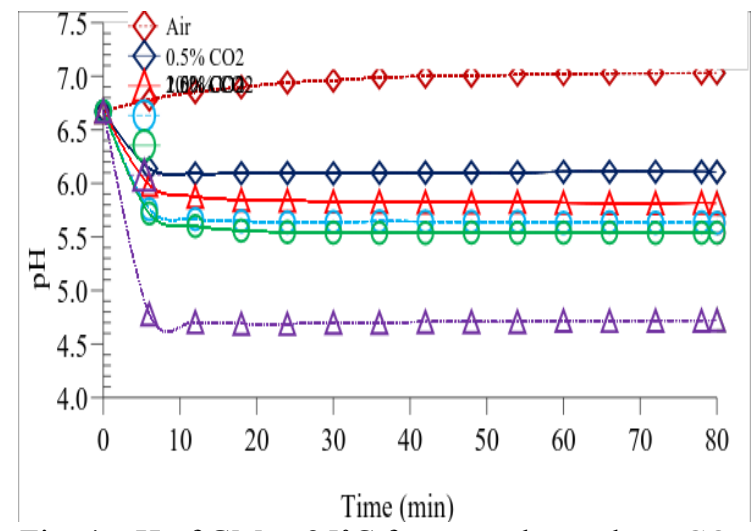

Fig. 4. $\mathrm{pH}$ of $\mathrm{GM}$ at $25^{\circ} \mathrm{C}$ for several gas phase $\mathrm{CO}_{2}$ concentrations 


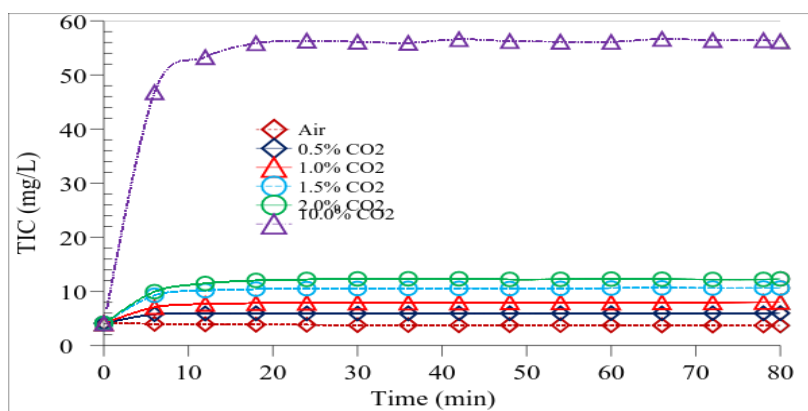

Fig. 5. TIC concentration in $\mathrm{GM}$ at $25^{\circ} \mathrm{C}$ for several gas phase $\mathrm{CO}_{2}$ concentrations

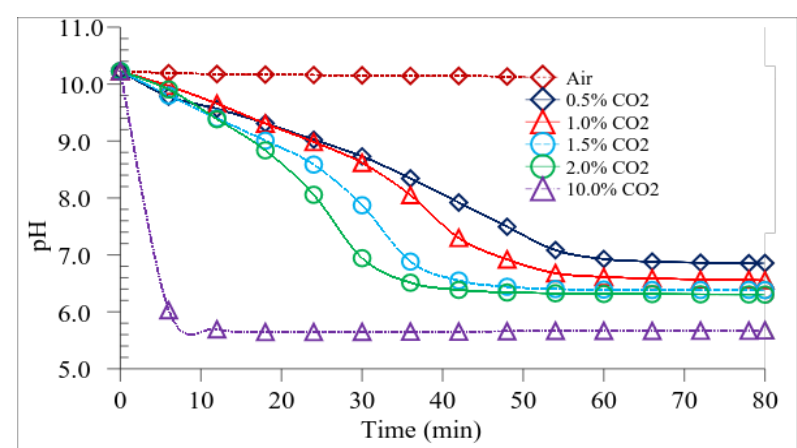

Fig. 6. $\mathrm{pH}$ of $\mathrm{GM}+$ at $25^{\circ} \mathrm{C}$ for several gas phase $\mathrm{CO}_{2}$ concentrations

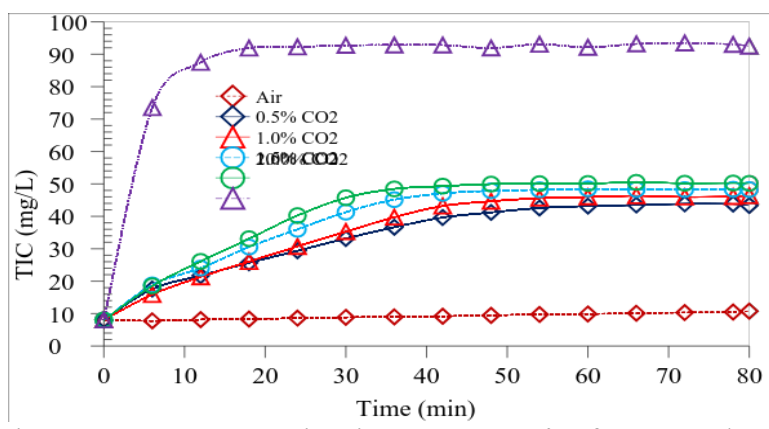

Fig. 7. TIC concentration in $\mathrm{GM}+$ at $25^{\circ} \mathrm{C}$ for several gas phase $\mathrm{CO}_{2}$ concentrations

The results for TIC concentration and $\mathrm{pH}$ as a function of time for GM and GM+ media are consistent with the results found with $\mathrm{RO}$ water and $\mathrm{RO}+$ media. Specifically, as TIC levels increase, $\mathrm{pH}$ decreases. And as TIC levels reach saturation values (or equilibrium), $\mathrm{pH}$ tends to reach equilibrium.

\section{B. Determining Saturation $\mathrm{pH}$}

The media $\mathrm{pH}$ from each experimental condition is shown in Table 1. TIC concentrations were taken from three replicate analysis of each media sample and averaged for each reported value. To determine the saturation value for $\mathrm{pH}$, the last five data points of $\mathrm{pH}$ corresponding to the last five values of TIC concentration (used to find TIC saturation) were averaged and reported as the saturation $\mathrm{pH}$ for that specific condition. These data were also used to calculate standard deviation (STDEV), coefficient of variance $(\mathrm{CV})$, absolute and relative errors. However, the STDEVs for RO water and GM, and $\mathrm{RO}+$ and $\mathrm{GM}+$ for
$\mathrm{CO}_{2}$ concentrations of $1.5 \%, 2.0 \%$ and $10 \%$ were less than 0.008 , whereas it was below 0.1 for $\mathrm{RO}+$ and $\mathrm{GM}+$ for air, and $0.5 \%$ and $1.0 \% \mathrm{CO}_{2}$. Therefore, only saturated $\mathrm{pH}$ in $\mathrm{RO}$ water, $\mathrm{RO}+\mathrm{GM}$ and $\mathrm{GM}+$ are reported.

Table 1 Saturated media $\mathrm{pH}$

\begin{tabular}{|c|c|c|c|c|c|}
\hline \multicolumn{4}{|c|}{ Media $\mathrm{pH}$} & \multirow[t]{2}{*}{$\mathrm{T}\left({ }^{\circ} \mathrm{C}\right)$} & \multirow[t]{2}{*}{$\% \mathrm{CO}_{2}$} \\
\hline GM+ & GM & $\mathrm{RO}+$ & RO & & \\
\hline 10.11 & 7.03 & 10.03 & 6.02 & 25 & Air \\
\hline 9.82 & 6.99 & 9.67 & 6.20 & 35 & \\
\hline 9.50 & 7.04 & 9.35 & 6.20 & 45 & \\
\hline 9.28 & 7.09 & 9.14 & 6.22 & 55 & \\
\hline 7.49 & & & & 25 & 0.1 \\
\hline - & & & & 35 & \\
\hline 7.51 & & & & 45 & \\
\hline 7.50 & & & & 55 & \\
\hline 6.88 & 6.11 & 6.71 & 5.14 & 25 & 0.5 \\
\hline 7.03 & 6.15 & 6.80 & 5.28 & 35 & \\
\hline 7.04 & 6.22 & 6.90 & 5.31 & 45 & \\
\hline 7.29 & 6.23 & 6.95 & 5.30 & 55 & \\
\hline 6.58 & 5.82 & 6.40 & 4.88 & 25 & 1.0 \\
\hline 6.62 & 5.84 & 6.48 & 4.90 & 35 & \\
\hline 6.73 & 5.86 & 6.61 & 4.95 & 45 & \\
\hline 6.87 & 5.89 & 6.65 & 4.96 & 55 & \\
\hline 6.39 & 5.63 & 6.24 & 4.77 & 25 & 1.5 \\
\hline 6.48 & 5.66 & 6.29 & 4.81 & 35 & \\
\hline 6.61 & 5.72 & 6.42 & 4.88 & 45 & \\
\hline 6.69 & 5.74 & 6.50 & 4.87 & 55 & \\
\hline 6.31 & 5.54 & 6.15 & 4.72 & 25 & 2.0 \\
\hline 6.34 & 5.51 & 6.19 & 4.65 & 35 & \\
\hline 6.44 & 5.63 & 6.26 & 4.68 & 45 & \\
\hline 6.57 & 5.60 & 6.42 & 4.76 & 55 & \\
\hline 5.67 & 4.72 & 5.56 & 4.21 & 25 & 10.0 \\
\hline 5.72 & 4.79 & 5.58 & 4.30 & 35 & \\
\hline 5.75 & 4.81 & 5.59 & 4.33 & 45 & \\
\hline 5.82 & 4.81 & 5.64 & 4.26 & 55 & \\
\hline
\end{tabular}

The data indicated that adding the $\mathrm{NaOH}$ solution in the media increased the value of saturation $\mathrm{pH}$ especially for RO water compared to RO water without the $\mathrm{NaOH}$ solution. The saturation $\mathrm{pH}$ and $\mathrm{pH}$ difference with and without the $\mathrm{NaOH}$ solution are tabulated in Table 2 .

Table 2 Saturated media $\mathrm{pH}$ difference

\begin{tabular}{llll}
\cline { 1 - 2 } $\mathrm{pH}$ Difference & \multicolumn{2}{c}{$\mathrm{CO}\left({ }^{\circ} \mathrm{C}\right)$} \\
\cline { 1 - 3 } GM \& GM+ & RO \& $\mathrm{RO}+$ & \\
\hline 3.08 & 4.01 & Air & 25 \\
0.77 & 1.57 & 0.5 & \\
0.76 & 1.52 & 1.0 & \\
0.76 & 1.47 & 1.5 & \\
0.77 & 1.43 & 2.0 & \\
0.95 & 1.35 & 10 & \\
\hline 2.83 & 3.47 & Air & 35 \\
0.88 & 1.52 & 0.5 & \\
0.78 & 1.58 & 1.0 & \\
0.82 & 1.48 & 1.5 & \\
0.83 & 1.54 & 2.0 & \\
0.93 & 1.28 & 10 & \\
\hline
\end{tabular}


Table 2 (Continued)

\begin{tabular}{llll}
\hline \multicolumn{2}{c}{ pH Difference } & $\mathrm{CO}_{2}(\%)$ & \multirow{2}{*}{$\left(^{\circ} \mathrm{C}\right)$} \\
\cline { 1 - 3 } GM \& GM+ & RO \& RO+ & \\
\cline { 1 - 3 } 2.46 & 3.15 & Air & 45 \\
0.82 & 1.59 & 0.5 & \\
0.87 & 1.66 & 1.0 & \\
0.89 & 1.54 & 1.5 & \\
0.81 & 1.58 & 2.0 & \\
0.94 & 1.26 & 10 & \\
\hline 2.19 & 2.92 & Air & 55 \\
1.06 & 1.65 & 0.5 & \\
0.98 & 1.69 & 1.0 & \\
0.95 & 1.63 & 1.5 & \\
0.97 & 1.66 & 2.0 & \\
1.01 & 1.38 & 10 & \\
\hline
\end{tabular}

C. Saturation $\mathrm{pH}$ as a Function of Temperature

Media $\mathrm{pH}$ data from Table 1 for GM and GM+ were plotted as a function of temperature in Figs. 8 and 9 for $\mathrm{GM}$ and $\mathrm{GM}+$, respectively. The media $\mathrm{pH}$ inconsistently increased with respect to increased temperature for all $\mathrm{CO}_{2}$ concentrations except ambient $\mathrm{CO}_{2}$ at this temperature range. Gradually increasing the TIC value and decreasing of the media $\mathrm{pH}$ for the experiment with ambient air indicated that the system was not at equilibrium. Very dilute $\mathrm{CO}_{2}$ levels in ambient air resulted in a low pseudo$\mathrm{CO}_{2}$ mass transfer coefficient and required a much long period of time to reach equilibrium.

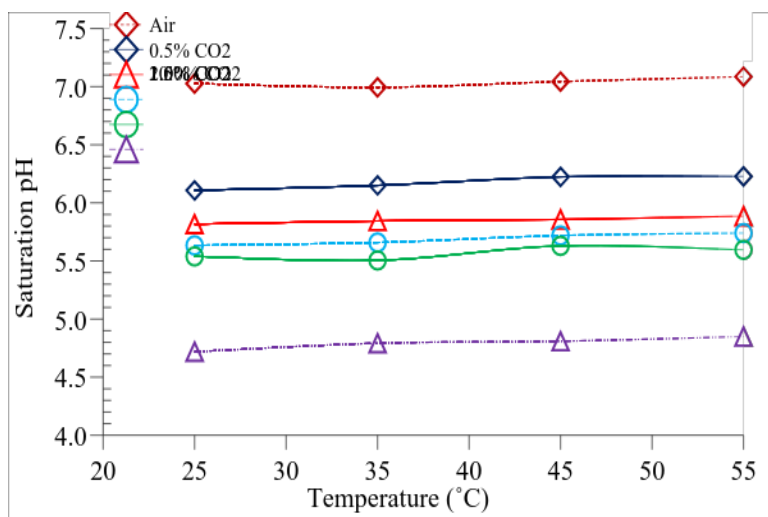

Fig. 8. Saturation $\mathrm{pH}$ in GM as a function of temperature

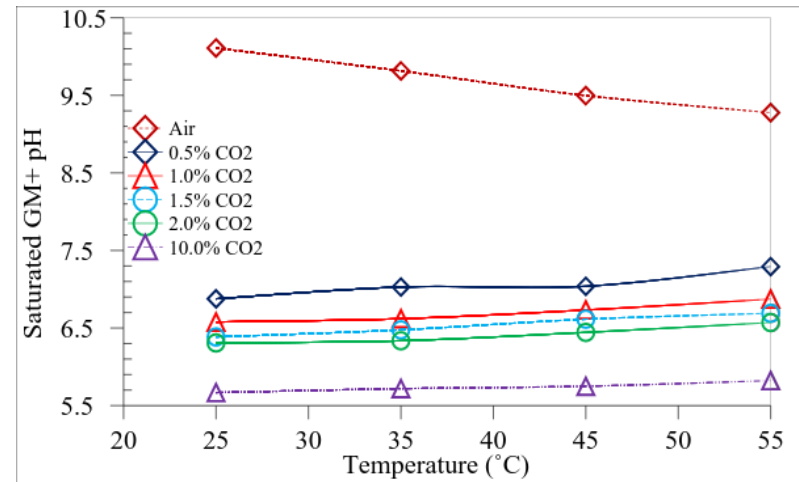

Fig. 9. Saturation $\mathrm{pH}$ in $\mathrm{GM}+$ as a function of temperature
D. Saturation $\mathrm{pH}$ as a Function of $\mathrm{CO}_{2}$ Concentration Data from Table 1 were plotted in Figs. 10 and 11 for RO, $\mathrm{RO}+, \mathrm{GM}$ and $\mathrm{GM}+$ at 25 and $55^{\circ} \mathrm{C}$ for gas phase $\mathrm{CO}_{2}$ concentrations of $0.5 \%, 1.0 \%, 1.5 \%$, and $2 \%$.

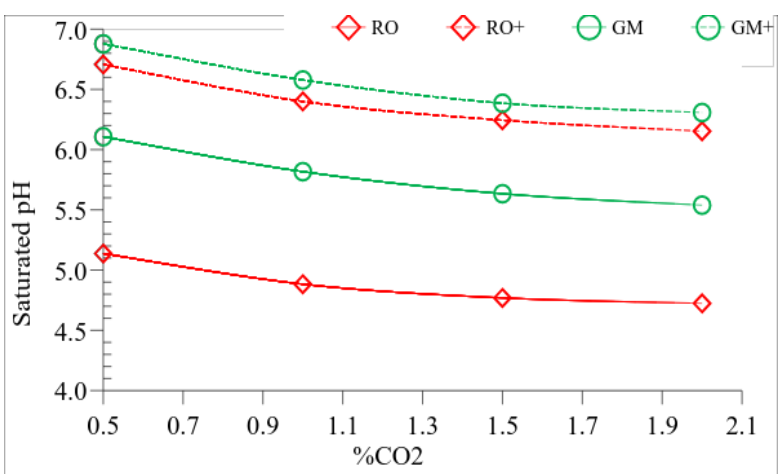

Fig. 10. Saturation $\mathrm{pH}$ at $25{ }^{\circ} \mathrm{C}$ as a function of $\mathrm{CO}_{2}$ concentration

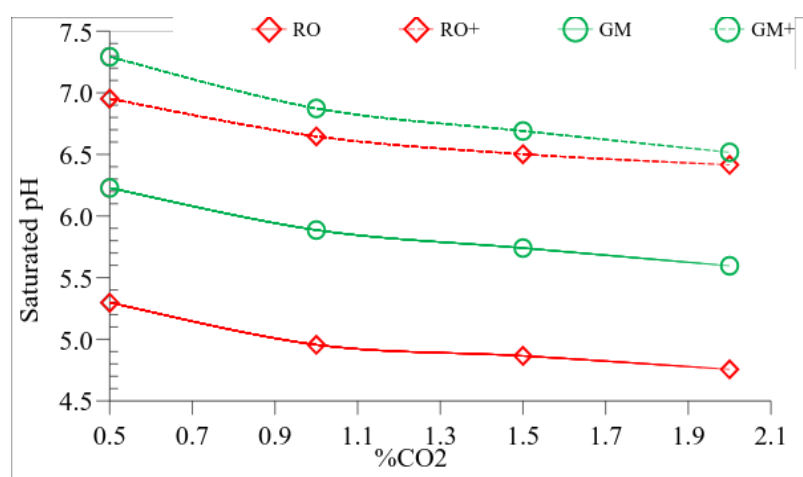

Fig. 11. Saturation $\mathrm{pH}$ at $55{ }^{\circ} \mathrm{C}$ as a function of $\mathrm{CO}_{2}$ concentration

Saturation $\mathrm{pH}$ shown in all cases in Figs. 10 and 11 was nonlinear with respect to change of the gas phase $\mathrm{CO}_{2}$ concentration. Driving force for $\mathrm{CO}_{2}$ solubility increased with respect to increased $\mathrm{CO}_{2}$ concentration; a high $\mathrm{CO}_{2}$ concentration provided high TIC concentration compared to a low $\mathrm{CO}_{2}$ concentration. A higher TIC concentration reduced the saturation $\mathrm{pH}$.

\section{CONCLUSION}

Media $\mathrm{pH}$ inversely followed TIC values for all experimental conditions. However, an exact correlation between decreasing TIC concentration and increasing the media $\mathrm{pH}$ is complex to determine because of the combined effects of temperature, $\mathrm{CO}_{2}$ level, media chemistry and even the accuracy of the $\mathrm{pH}$ probe.

However, the trends were observed. Although the TIC concentration nonlinearly decreased with respect to increased temperature, the saturation $\mathrm{pH}$ linearly increased. Conversely, as the TIC concentration linearly increased with respect gas phase $\mathrm{CO}_{2}$ concentration, the saturation $\mathrm{pH}$ nonlinearly decreased. The saturation value of TIC and $\mathrm{pH}$ were reached at the same time. This indicates that equilibrium $\mathrm{pH}$ may be used to specify the 


\section{International Advanced Research Journal in Science, Engineering and Technology}

ISO 3297:2007 Certified

Vol. 3, Issue 11, November 2016

saturation condition of TIC. However, the saturation $\mathrm{pH}$ with unknown initial $\mathrm{pH}$ cannot be used to quantify the amount of TIC concentration especially when the media consists of various chemical species.

\section{ACKNOWLEDGMENT}

I would like to express my sincere thanks to staffs and everybody at Institute for Sustainable Energy and the Environments, Ohio University, USA.

\section{REFERENCES}

[1] J. Kalff, 2002, Limnology: Inland Water Ecosystems, Prentice Hall, Upper Saddle River, MA, Chap. 14.

[2] W. Stumm, and J. J. Morgan, 1996, Aquatic Chemistry: Chemical Equilibria and Rates in Natural Water $3^{\text {rd }}$ Edition, John Wiley \& Son, New York, NY.

[3] K. Al-Anezi, and N. Hilal, "Scale formation in desalination plants: Effect of carbon dioxide solubility," Desalination, vol. 204, pp. 385-402, 2007.

[4] C. Y. Chen, and E. G. Durbin, "Effects of pH on the growth and carbon uptake of marine phytoplankton," Mar. Ecol. Prog. Ser., vol. 109, pp. 83-94, 1994.

[5] Y. Shiraiwa, S. Yokoyama, and A. Satoh, "pH-dependent regulation of carbonic anhydrase induction and change in photosynthesis during adaptation of Chlorella cells to low $\mathrm{CO}_{2}$," Jpn. J. Phycol. (Sôrui), vol. 39, pp. 355-362, 1991.

[6] H.T. Hsueh, H. Chua, and S.T. Yu, "A batch study on the biofixation of carbon dioxide in the absorbed solution from a chemical wet scrubber by hot spring and marine algae," Chemosphere, vol. 66, pp. 878-886, 2007.

[7] W. A. Dodd, and R. G. S. Bidwell, "The Effect of $\mathrm{pH}$ on the Products of Photosynthesis in ${ }^{14} \mathrm{CO}_{2}$ by Chloroplast Preparations from Acetabularia mediterranea," Plant Physiol., vol.47, pp. 779783, 1971.

[8] D. C. O. Thronton, "Effect of Low pH on Carbohydrate Production by a Marine Planktonic Diatom (Chaetoceros muelleri)," Research Letters in Ecology., 2009, pp. 1-4, 2009.

[9] E. Granum, and S. M. Myklestad, "A photobioreactor with pH control: demonstration by growth of the marine diatom Skeletonema costatum," J. Plankton Res., vol. 24, pp. 557-563, 2002.

[10] J. Uusitalo, "Algal carbon uptake and the difference between alkalinity and high $\mathrm{pH}$ ("alkalization"), exemplified with a $\mathrm{pH}$-drift experiment," Sci. Mar., vol. 60 (Supl. 1), pp. 129-134, 1996.

[11] J. L. Greenwood, and R. L. Lowe, "The effects of $\mathrm{pH}$ on a periphyton community in an acidic wetland, USA," Hydrobiologia, vol. 561, pp. 71-82, 2006.

[12] M. Berenguel, F. Rodríguez, F. G. Acién, and J. L. García, "Model predictive control of $\mathrm{pH}$ in tubular photobioreactors," J. Process Contr., vol. 14, pp. 377-387. 2004.

[13] A. G. Miller, D. H. Turpin, and D. T. Canvin, " $\mathrm{Na}^{+}$Requirement for Growth Photosynthesis, and pH Regulation in the Alkalotolerant Cyanobacterium Synechococcus leopoliensis," J. Bacteriol., vol. 159(1), pp. 100-106, 1984.

[14] A. Bano, and P. J.A. Siddiqui, "Characterization of Five Marine Cyanobacterial Species with Respect to Their $\mathrm{pH}$ and Salinity Requirements," Pak. J. Bot., vol. 36(1), pp. 133-143, 2004

[15] C. E. W. Steinberg, H. Schafer, and W. Beisker, "Do Acid-tolerant Cyanobacteria Exist?," Acta Hydroch. Hydrob., vol. 26(1), pp. 13$19,1998$.

[16] N. Thajuddin, and G. Subramanain, "Cyanobacterial Biodiversity and Potential Applications in Biotechnology," Curr. Sci. India, vol. 89(1), pp. 47-57, 2005.

[17] C. Dasaard, D. J. Bayless, and B. J. Stuart, "Experimental Measurement of Total Inorganic Carbon Concentrations from Absorption of Gas Phase $\mathrm{CO}_{2}$, IARJSET, vol. 3, pp. 119-125, Oct. 2016 .

\section{BIOGRAPHY}

Chalermsak Dasaard, Ph.D., completed B.S.M.E. from Chulachomklao Royal Military Academy (CRMA), Thailand and earned M.S.M.E. and Ph.D. in Mechanical and Systems Engineering from Ohio University, USA. I am an instructor in Mechanical Engineering Department, Academic Division, CRMA, Thailand. My research interests are Renewable Energy and Waste Conversion. 